\title{
Correction to: 3D Simulation of Transient Thermal Response of Mucuna Seed subjected to Laser Heating: A Parametric Study Approach
}

\author{
I. T. Horsfall ${ }^{1,3}$ A. O. Igbozulike ${ }^{1}$ N. R. Nwakuba ${ }^{2}$ M. C. Ndukwu ${ }^{1}$ (D) O. I. Daniel $^{4} \cdot$ Merlin Simo-Tagne $^{5}$
}

Accepted: 14 August 2021 / Published online: 30 August 2021

(C) The Institution of Engineers (India) 2021

\section{Correction to: J. Inst. Eng. India Ser. A https://doi.org/10.1007/s40030-021 $-00563-8$}

The original version of this article was published online on August 5, 2021, unfortunately contained a mistake. The Corresponding author name spelling was incorrect.

It previously read as:

M. C. Nduwku

It should read as:

M. C. Ndukwu

The Original article has been corrected.

Publisher's Note Springer Nature remains neutral with regard to jurisdictional claims in published maps and institutional affiliations.

The original article can be found online at https://doi.org/10.1007/s40030-021-00563-8.

M. C. Ndukwu

ndukwumcu@mouau.edu.ng

1 Department of Agricultural and Bioresources Engineering, Michael Okpara University of Agriculture, Umudike, Nigeria

2 Department of Agricultural and Bioresources Engineering, Federal University of Technology, Owerri, Nigeria

3 Department of Environmental Engineering, Ibibath MultiService, Port Harcourt, Nigeria

4 Department of Agricultural and Food Engineering, University of Uyo, Akwa Ibom State, Nigeria

5 Academie de Nancy-Metz, 54035, 2 rue Philippe de Gueldres, 54000 Nancy, France 